\title{
Synthesis of DEAE-Soybean Starch Microspheres for Adhere Animal Cell Culture
}

\author{
Lei Zhang ${ }^{1,2}$, Mingsheng $\mathrm{Li}^{1,2,3}$, Zhongren $\mathrm{Ma}^{1,2,3}$ \& Yuping Feng ${ }^{1,2,3}$ \\ ${ }^{1}$ Key Laboratory of Bioengineering \& Biotechnology of State Ethnic Affair Commission, Northwest Minzu \\ University, Lanzhou, Gansu, China \\ ${ }^{2}$ College of Life Science and Engineering, Northwest Minzu University, Lanzhou, Gansu, China \\ ${ }^{3}$ Gansu Engineering Technology Research Center for Animal Cell, Northwest Minzu University, Lanzhou, Gansu, \\ China
}

Correspondence: Yuping Feng, College of Life Science and Engineering, Northwest Minzu University, No.1 Xibeixinxun, Lanzhou, Gansu 730030, China. Tel: 86-931-2938311. E-mail: fyp@xbmu.edu.cn

Lei Zhang, College of Life Science and Engineering, Northwest Minzu University, No.1 Xibeixinxun, Lanzhou, Gansu 730030, China. E-mail: 1tzhanglei@qq.com

Received: May 7, 2017

Accepted: June 26, $2017 \quad$ Online Published: July 15, 2017

doi:10.5539/jas.v9n8p91

URL: https://doi.org/10.5539/jas.v9n8p91

\begin{abstract}
The present study outlines the synthesis of a new microcarrier for anchorage-dependent animal cell cultures. The new microcarriers were synthesized from the cross-linking soybean starch microspheres followed by modification with 2-diethylaminoethyl (DEAE). Furthermore, $5 \mathrm{~g} / 100 \mathrm{~mL}$ of wet microspheres DEAE-soybean starch microspheres were applied in the adhere cell culture, with an inoculation density $2.0 \times 10^{5}$ cells $/ \mathrm{mL}$ of BHK-21, Marc-145, and MDCK cells. The cells were shown to grow well in the DEAE-soybean starch microcarrier, with BHK-21 cells showing a higher cell density after $144 \mathrm{~h}\left(2.5 \times 10^{6}\right.$ cells $\left./ \mathrm{mL}\right)$ compared to cells grown on the commercial product Cytodex $1\left(2.2 \times 10^{6}\right.$ cells $\left./ \mathrm{mL}\right)$. These starch microcarriers have a potential application in anchorage-dependent animal cells culture, due to its low cost and its simple process.
\end{abstract}

Keywords: soybean starch, starch microspheres, microcarrier, adhere animal cell culture

\section{Introduction}

Most animal cells cultures in vitro require wall anchorage to attach and grow (Freshney, 2010). Microcarrier is non-toxic, non-rigid and transparent microspheres of uniform density, on which allows the growth of adherent cell cultures. The microcarriers suspends in the culture medium, increasing the density of microcarriers will increase the cell density. Thus, the application of the microcarriers is advantageous to the cell mass culture and harvesting. Currently, Microcarriers are widely used in the biological pharmaceutical field, including in the production of vaccines, recombinant protein drugs, monoclonal antibodies, cytokines and their receptors, and other medical biological products (Rodrigues et al., 2013; Costa et al., 2013; Ting et al., 2014; Stich et al., 2014; Park et al., 2014; Nienow et al., 2014).

In 1967, the first microcarrier Sephadex A-50 for cell culture was developed by Van Wezel (van Wezel, 1967) using 2-diethylaminoethyl (DEAE) then, several microcarrier materials have been developed, including glucan(van Wezel, 1967), cellulose (Paris et al., 1983), chitosan (Chen et al., 2006), glucomannan (Sun et al., 2010) and polymer molecules (Reuveny et al., 1983; Gumusderelioglu et al., 2013; Zuhlke et al., 1993; Cer et al., 2007). The commercial microcarrier products in the market are GE Cytodex I, II and III, Cytopore, and Cultispher G. All these products are expensive, limits their application in the pharmaceutical industries. Thus, to develop an inexpensive microcarrier for animal cell culture using easily acquired polymeric raw materials has a great potential.

Starch is a cheap and accessible biological material widely used in food, medicine, textiles, and other industrial applications. The structure of starch, with its large number of hydroxyl groups, can easily undergo chemical modification of its backbone, and has thus become a potential polymer for the development of new microcarrier materials. Starch microspheres with a large porous surface area and accessible reactive groups such as hydroxyls (Delval et al., 2005) have therefore been used as drug carriers (Björses et al., 2011; Edman et al., 1992) and 
adsorbents (Yuan et al., 2015; Song et al., 2004). The structure of these microspheres makes it possible for chemically modification of starch backbone according to the necessary requirements. Furthermore, DEAE is well known as a surface modifier substance for microcarriers.

The present study describes the synthesis of new starch microsphere as an natural polymer microcarrier and explores its preliminary application in adherent cell cultures. Starch microspheres were synthesized by coupling with DEAE through ion exchange leading to the preparation of starch microsphere microcarriers suitable for adherent cell growth. The starch microcarriers were used to grow suspension cultures of Baby Hamster Syrian Kidney (BHK-21), Marc-145, and MDCK cells. GE product Cytodex 1 was used as the microcarrier for the control group. The suitability of DEAE-soybean starch microspheres as microcarriers was evaluated through cell growth curves, through the cell growth profile, and the observation of morphological characterization by Giemsa and Hoechst 33258 staining.

\section{Materials and Method}

\subsection{Materials}

Soybean starch (commercial), machine oil (15w-40, Shell, USA), 2-(Diethylamino) ethyl chloride hydrochloride (99\%, Aladdin, China), all other chemical reagents were ordinary analytical reagents. BHK-21, Marc-145, and MDCK cells were from the ATCC (USA). Dulbecco's modified Eagle medium (DMEM) were from Gibco. Newborn Calf Serum (NBCS) was from Lanzhou Minhai biotechnology Co., Ltd (China). Cytodex 1 microcarriers were from GE Healthcare (Uppsala, Sweden). BHK-21, Marc-145, and MDCK cells were cultured in DMEM supplemented with $10 \%$ NBCS. The cells were cultivaed at $37{ }^{\circ} \mathrm{C}$ in a humidified atmosphere with $5 \% \mathrm{CO}_{2}$.

\subsection{Methods}

\subsubsection{Synthesis of Soybean Starch Microsphere (CSM)}

The soybean starch microspheres were synthetized through two processes. The water phase was $15 \mathrm{~g}$ of soybean starch powder in $200 \mathrm{~mL}$ of distilled water, heated to the gelatinization point while stirring. Then a $6 \mathrm{M} \mathrm{NaOH}$ solution was then added until $\mathrm{pH} 14$ the solution was then cooled to room temperature. The oil phase was 1000 $\mathrm{mL}$, machine oil $(50 \%, \mathrm{v} / \mathrm{v})$ and isooctane $(50 \%, \mathrm{v} / \mathrm{v})$, and $2 \%$ span- 80 . Water phase was slowly added to oil phase during continuously stirring for approximately 20 minutes at $500 \mathrm{rpm}$.

Polyethylene-glycol-diglycidyl-ether $(20 \mathrm{ml})$ was added whilst mixing, and the crosslinking reaction was allowed to continue for 6 hours. Following the completion of the crosslinking reaction, the solution was left to stand until phase separation was observed. The oil layer was removed and the lower sediment was washed with a $2 \%$ op-10 emulsifier solution and then pure water 2 to 4 times. Soybean starch microspheres with diameters between 120 and $200 \mu \mathrm{m}$ were then sieved and used for further modification.

\subsubsection{Synthesis of DEAE-Soybean Starch Microspheres (DEAE-CSM)}

Sieved soybean starch microspheres (wet microspheres; $10 \mathrm{~g}$ ) were added to $20 \mathrm{~mL}$ of $4.5 \mathrm{~mol} / \mathrm{L}$ sodium hydroxide solution and stirred for $10 \mathrm{~min} ; 20 \mathrm{~mL}$ of $3.5 \mathrm{~mol} / \mathrm{L}$ 2-(Diethylamino) ethyl chloride hydrochloride solution were then added and the mixture was heated to $60{ }^{\circ} \mathrm{C}$ with continuous stirring at $300 \mathrm{rpm}$ for 4 hours. Following the reaction, phosphate buffered saline (PBS; without potassium, calcium, or magnesium ions) was added the microspheres were washed 2 to 4 times with water until the $\mathrm{pH}$ was neutral.

\subsubsection{Spinner Flask Culture}

BHK-21, Mark-145, and MDCK cells were thawed and cultured in a T75 cell culture flask. DMEM with 10\% NBCS were used. Linked DEAE-soybean starch microspheres (DEAE-CSM) microcarriers (5 g wet microspheres) were placed into a conical flask and washed three times with PBS. The microcarriers were autoclaved in $30 \mathrm{~mL}$ PBS before use. Cells were grown in $50 \mathrm{~mL}$ cultures in $125 \mathrm{~mL}$ spinner bottles (Techne, UK) and maintained at $37{ }^{\circ} \mathrm{C}$. DEAE-CSM and Cytodex 1 microcarriers, prepared according to manufactures instructions, were used at a density of $5 \mathrm{~g} / 100 \mathrm{~mL}$ (wet microspheres) and inoculated with $20 \mathrm{~mL} 2.0 \times 10^{5}$ cells $/ \mathrm{mL}$. The initial attachment of cells was performed in a half working volume $(50 \mathrm{~mL})$, as follows: $5 \mathrm{~min}$ of stirring at $35 \mathrm{rpm}$ followed by $30 \mathrm{~min}$ of non-stirring, for a total duration of $6 \mathrm{~h}$. After this continuous stirring, 45 RPM, was used. After 24 hours $50 \mathrm{~mL}$ of medium were added and $3 \mathrm{~mL}$ samples were retrieved for cell counting every $24 \mathrm{~h}$ for 8 days. 


\subsubsection{Observation of Cell Morphology}

(1) Cells for Giemsa Staining on the Microcarriers

Microcarrier cultures $(1 \mathrm{~mL})$ were transferred to a sample tube, after 5 min the supernatant was removed. Samples were washed twice with calcium-and magnesium-free PBS buffer. Fixation buffer (PBS buffer: methanol mixture $=1: 1 ; 1 \mathrm{~mL}$ ) was added for $2 \mathrm{~min}$ and the supernatant was removed after 5 min. Methanol (2 $\mathrm{mL}$ ) was then added and the samples were incubated for $10 \mathrm{~min}$. Giemsa staining concentrate (Sigma, US) was diluted 10 times in PBS buffer and $2 \mathrm{~mL}$ were added to the sample tube, after mixing they were incubated 2 min. The microcarriers were washed with pure water five times and a few drops were placed in concave slides and observed in an inverted phase contrast microscope (IX51-FL, Olympus China co., Ltd.).

(2) Cells for Hoechst 33258 Staining on the Microcarriers

Microcarrier cultures $(1 \mathrm{~mL})$ were transferred to a sample tube after 5 min the supernatant was removed. Samples were washed three times with $0.9 \%$ saline. Fixation medium (acetic acid: methanol $=1: 3 ; 2 \mathrm{~mL}$ ) was then added. After $5 \mathrm{~min}$, the supernatant was removed and a new addition of $2 \mathrm{~mL}$ of fixation medium was made. After $10 \mathrm{~min}$ the fixation liquid was discarded and the samples were washed three times with $0.9 \%$ saline, followed by the addition of $2 \mathrm{~mL}$ Hoechst 33258 (Sigma, US) $(1 \mu \mathrm{g} / \mathrm{mL}$ ). The mixture was left in dark conditions for 10 to $15 \mathrm{~min}$ at room temperature. The dyeing liquid was removed and the samples were washed three times with $0.9 \%$ saline and observed in a fluorescent inverted microscope (CK40-32, Olympus China co., Ltd.).

\section{(3) Cell Growth Curve}

The samples were collected daily to monitor cell growth. The cell morphology was observed using an inverted microscope, the cell density was determined using the crystal violet nuclei-staining method. Briefly, $1 \mathrm{~mL}$ of a well-mixed sample was washed twice with PBS, then treated with $1 \mathrm{~mL}$ of $0.1 \mathrm{~mol} / \mathrm{L}$ citric acid containing $0.1 \%$ crystal violet and incubated for $24 \mathrm{~h}$ at $37^{\circ} \mathrm{C}$. The released nuclei were counted using a hematocytometer. The Data were reported as mean \pm standard deviation of duplicated experiments.

(4) Characterization of the Soybean Starch, Starch Microsphere, DEAE-Soybean Starch Microsphere

The surface morphology of the soybean starch microsphere was observed using an optical microscope and scanning electron microscopy (SEM). For SEM observation, dry soybean starch microspheres (CSM) and Cytodex 1 microspheres were coated with platinum under vacuum using an ion sputter (JFC-1600, JEOL) and observed with a JSM-5600LV SEM (JEOL, Japan). An X'Pert PRO (PANalytical, Netherlands) X-ray diffractometer was used to measure the solid X-ray diffraction (XRD) diagram using $\mathrm{CuK} \alpha(\lambda=0.154 \mathrm{~nm})$ radiation at $36 \mathrm{kV}$ and $20 \mathrm{~mA}$, and a $3-50^{\circ} 2 \theta$ scan range at $4 \%$ min. Fourier transform infrared (FTIR) spectroscopy was performed on a Nicolet-5700 (Nicolet, USA) spectroscope in the mode of attenuated total reflectance for a wavelength range of $4000-500 \mathrm{~cm}^{-1}$.

\section{Results and Discussion}

\subsection{Characteristics of the Starch Microcarriers}

\subsubsection{Morphological Image Analysis}

Figures 1a and 1b show the SEM images of soybean starch, CSM. Natural soybean starch is amorphous or ovoid, with a smooth surface, uneven grain size and a few small particles are spherical (Hoover \& Ratnayake, 2002; Ratnayake et al., 2002). However, the starch CSM showed a regular spherical shape and a uniform particle size, with a rough and porous surface with an increased specific surface area, indicating that crosslinking occurred during the emulsion reaction. Figures $1 \mathrm{c}$ and $1 \mathrm{~d}$ show the morphology of CSM and DEAE-CSM particles observed with an optical microscope, indicating a regular shape and a uniform particle size distribution. 


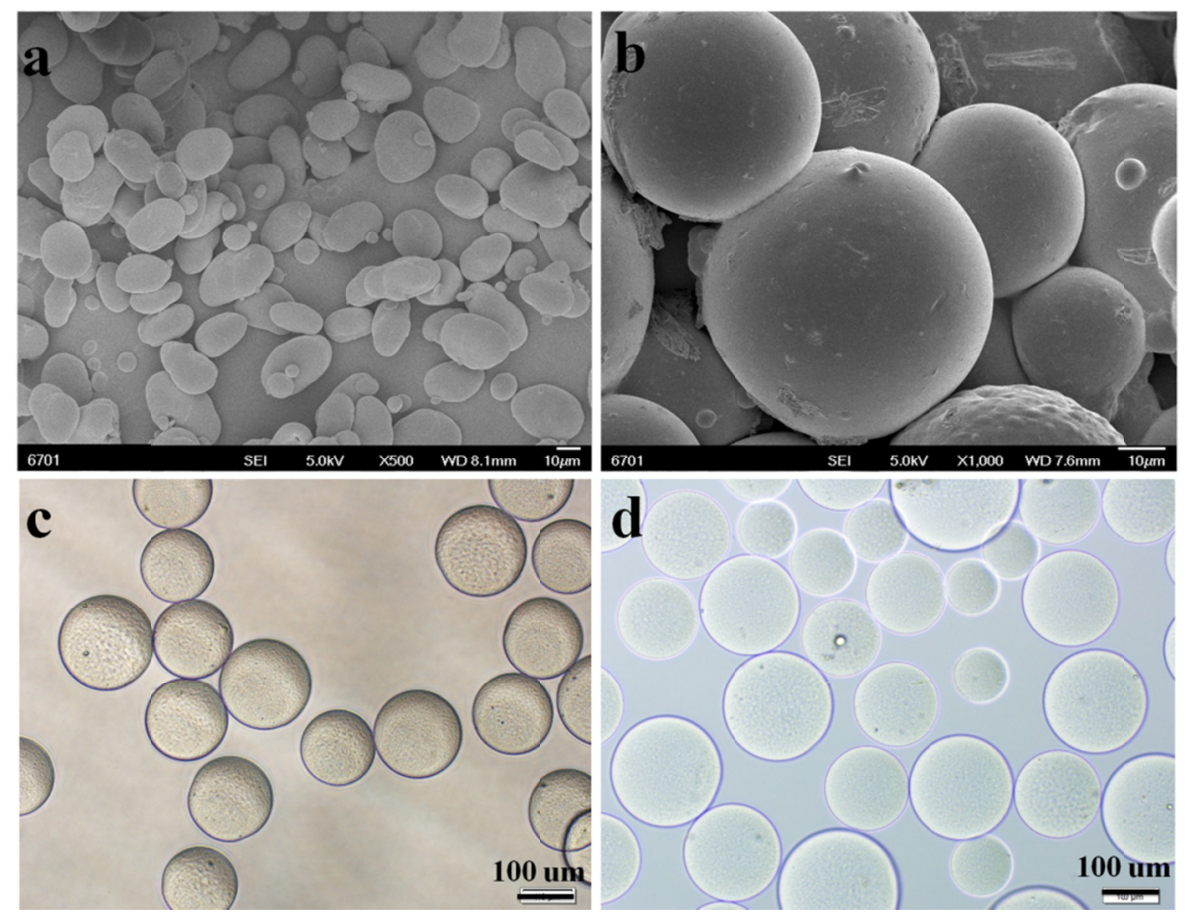

Figure 1. Morphology observation. (a) SEM image of soybean starch, (b) SEM image of CSM, (c) Microscope image of CSM, (d) Microscope image of DEAE-CSM

\subsubsection{XRD and FTIR Spectroscopy}

The XRD spectra of soybean starch, CSM, and DEAE-CSM are shown in Figure 2a. Soybean starch powder is a typical C type crystal, with type A and type B polycrystalline characteristics (Hoover \& Ratnayake, 2002), showing strong diffraction peak peaks at $2 \theta=5.5^{\circ}, 14.2^{\circ}, 17.2^{\circ}$, and $22.3^{\circ}$, typical of the soybean starch structure (Hoover \& Ratnayake, 2002; Ratnayake et al., 2002). However, these peaks disappeared from the soybean starch microsphere XRD pattern, and instead a wider non-crystalline peak appeared at approximately $25.7^{\circ}$. These changes were expected considering that, during crosslinking, co-polymerization weakens the inter-atomic forces of the molecular chain and the effect of hydrogen bonding between chains, resulting in a decrease in crystallinity.

Figure $2 \mathrm{~b}$ shows that the main characteristic peak of soybean starch is consistent with previous reports of soybean starch FTIR (Jayasekara et al., 2004; Helan et al., 2015). The soybean starch microspheres showed a strong peak at $3403 \mathrm{~cm}^{-1}$ due to a wide $\mathrm{O}-\mathrm{H}$ stretching vibration absorption band, indicating that this stretching band is retained following the crosslinking reaction, although it is narrower and at a slightly higher frequency due to hydrogen bonding following the crosslinking reaction. Further, the $3403 \mathrm{~cm}^{-1}$ band of the soybean starch microspheres is more prominent than for soybean starch due to the stretching superposition of the N-H and O-H stretching vibration absorption peaks. The $1121 \mathrm{~cm}^{-1}, 2935 \mathrm{~cm}^{-1}, 760 \mathrm{~cm}^{-1}$, and $1107 \mathrm{~cm}^{-1}$ absorption peaks observed belong to the $\mathrm{C}-\mathrm{H}$ stretching vibration and $\mathrm{C}-\mathrm{O}-\mathrm{C}$ asymmetric and symmetric stretching vibrations, respectively, of the starch glucose unit. These absorption peaks did not change significantly before and after crosslinking. Finally, the peak at approximately $1651 \mathrm{~cm}^{-1}$ belongs to the amide $\mathrm{C}=\mathrm{O}$ stretching vibration absorption peak. 
a

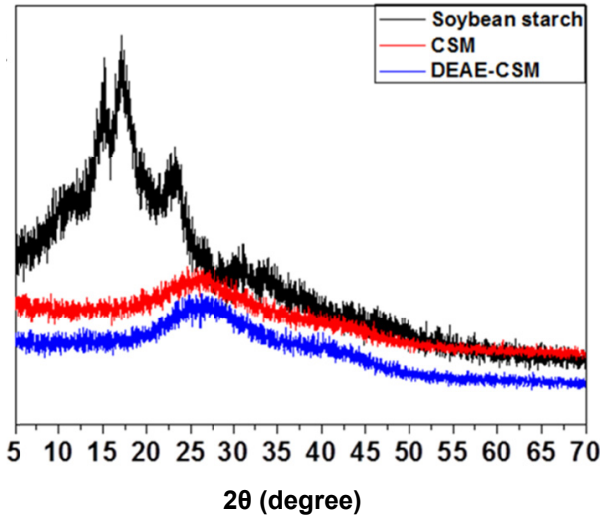

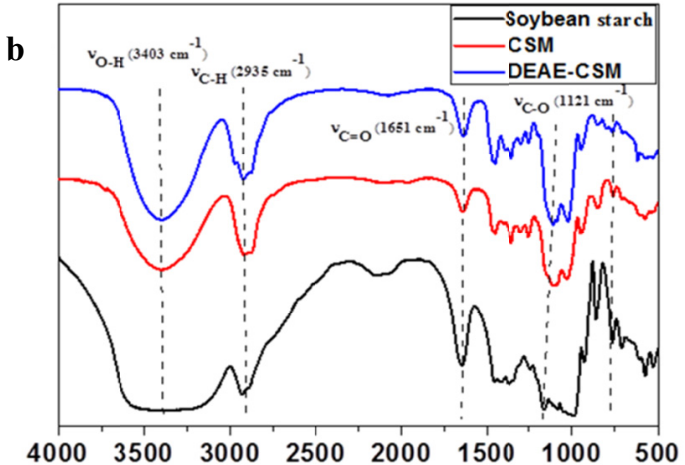

Figure 2. XRD and FTIR spectroscopy. (a) XRD patterns of soybean starch, CSM, and DEAE-CSM. (b) FTIR spectrum of starch, CSM, and DEAE-CSM

\subsection{The Result of Spinner Flask Culture}

Fluorescent staining showed that the cells grown on the DEAE-CSM microcarrier appeared blue and had a normal nuclear shape comparable to Cytodex 1 microcarriers (Figures 3a and 3b). After Giemsa staining, cells were dyed purple blue. Further, cells grown for $120 \mathrm{~h}$ on DEAE-CSM and Cytodex 1 microcarriers grow well, with good adhesion and cell morphology (Figures 3c and 3d). The DEAE-CSM microcarrier showed good biocompatibility with all three cell types, which shows DEAE-CSM microcarriers are suitable for these cell lines.
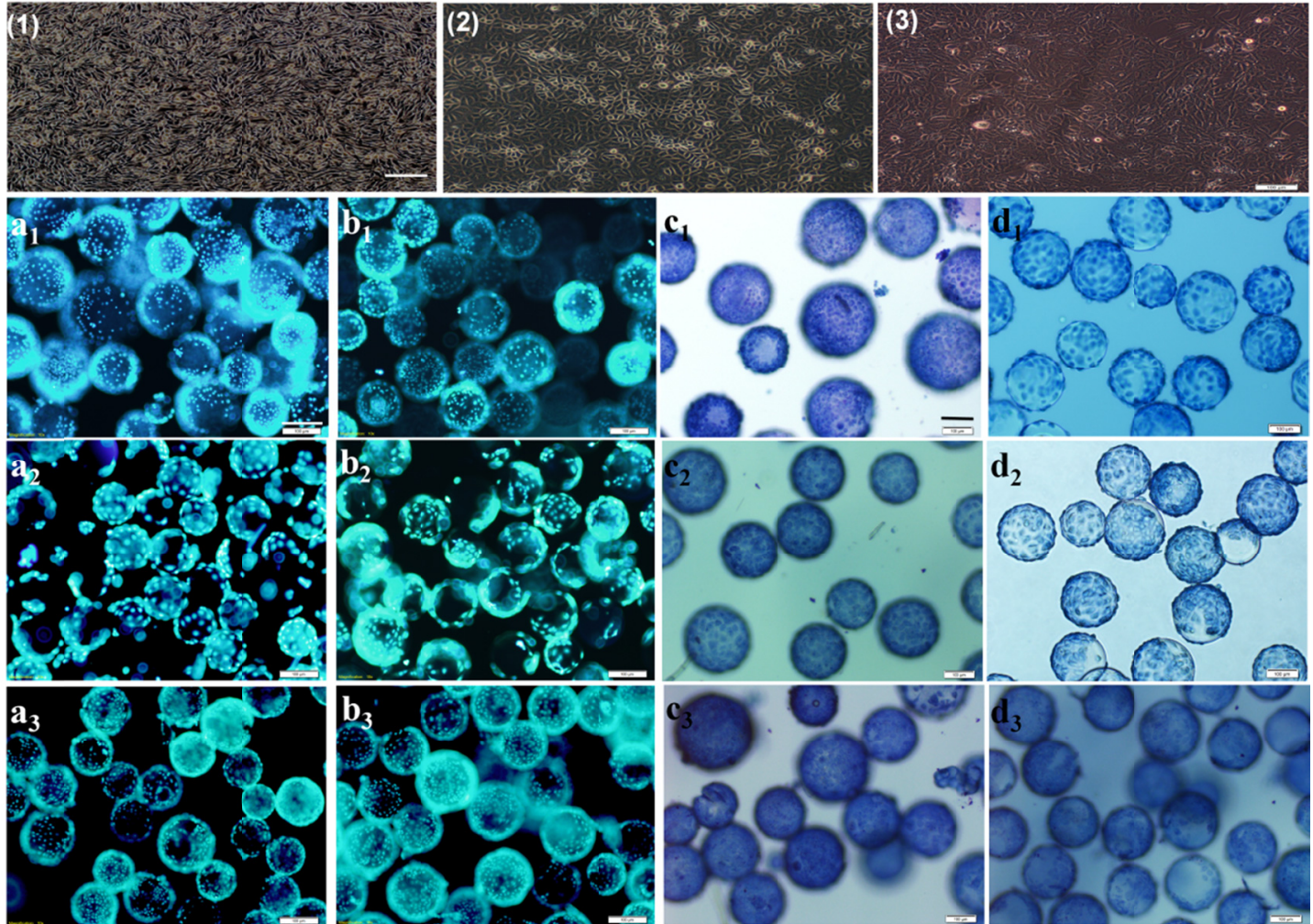

Figure 3. Microscopy images of three cell lines grown on (a, c) DEAE-CSM and (b, d) Cytodex 1 microcarriers.

(1) BHK-21, (2) Marc-145, (3) MDCK cells were inoculated at $2.0 \times 10^{5}$ cells $/ \mathrm{mL}$ onto $5 \mathrm{~g} / 100 \mathrm{~mL}$ (wet

microspheres) DEAE-CSM and Cytodex 1 microcarriers, respectively. (a, b) Cells were observed with

fluorescent inverted phase contrast microscopy after $96 \mathrm{~h}$ of cultivation by Hoechst 33258 staining. (c, d) Cells were observed with an inverted light microscope after $120 \mathrm{~h}$ of cultivation by Giemsa staining.

Scale bar is $100 \mu \mathrm{m}$ 

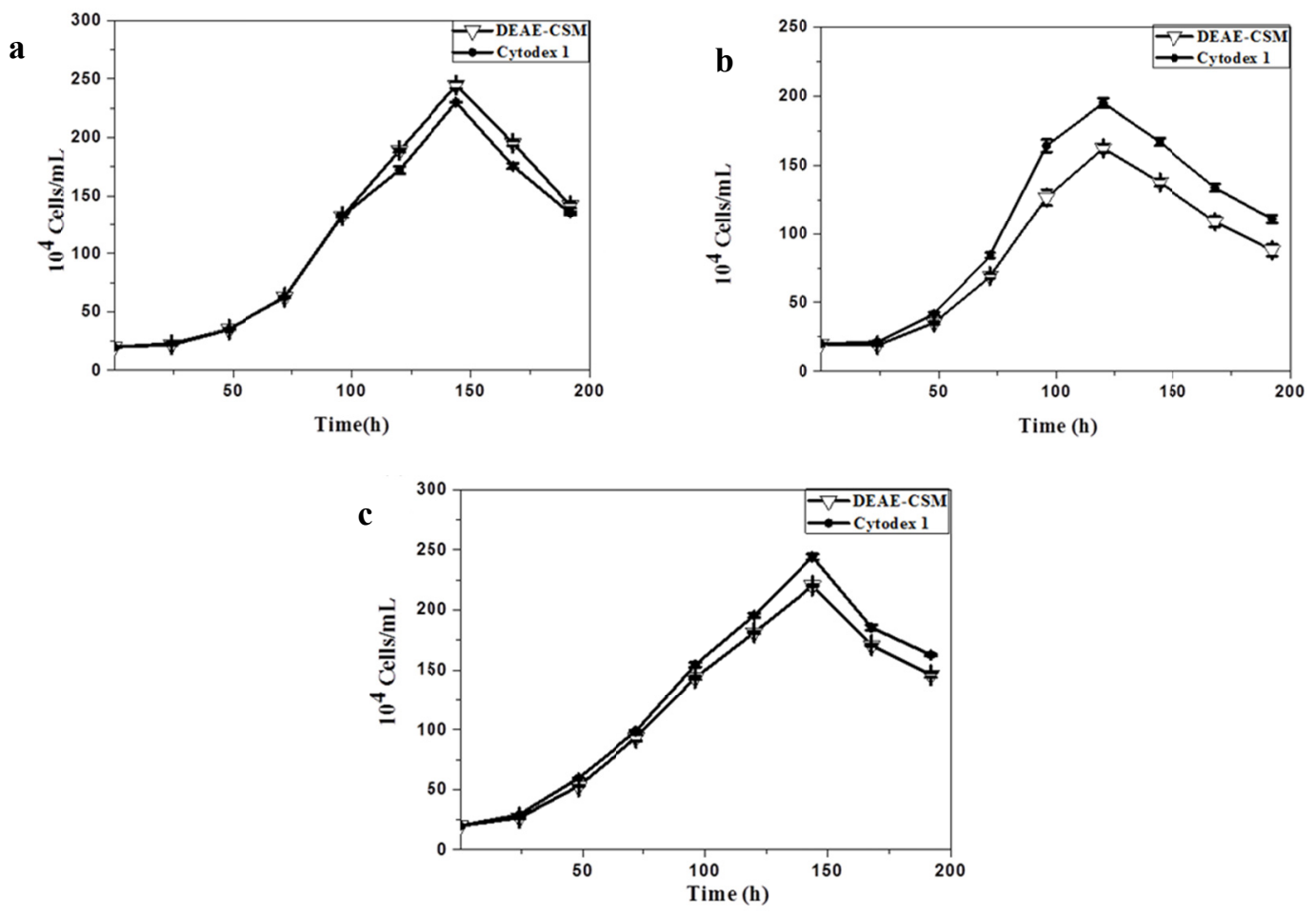

Figure 4. The growth curve of three cells on DEAE-CSM and Cytodex 1 microcarriers in spinners. (a) BHK-21, (b) Marc-145, and (c) MDCK

BHK-21, Marc-145, and MDCK cells were cultivated on the microcarrier suspensions of DEAE-CSM and Cytodex $1.20 \mathrm{~mL}$ of the cells at $2.0 \times 10^{5}$ cells $/ \mathrm{ml}$ were inoculated onto $5 \mathrm{~g} / 100 \mathrm{~mL}$ of wet microspheres of DEAE-CSM microcarriers and Cytodex 1 microcarriers. The cell growth curves on DEAE-CSM and Cytodex1 microcarriers are shown in Figure 4, indicating a similar growth trend, but only minor differences in cell density. After $144 \mathrm{~h}$ of growth, BHK-21 cells showed the highest cell density in the DEAE-CSM suspension $\left(2.5 \times 10^{6}\right.$ cells $/ \mathrm{ml}$ compared to $2.2 \times 10^{6}$ cells $/ \mathrm{ml}$, respectively, for Cytodex 1). The maximum proliferation of Marc-145 cells on the starch microcarrier and Cytodex 1 were $1.4 \times 10^{6}$ cells $/ \mathrm{mL}$ and $1.6 \times 10^{6}$ cells $/ \mathrm{mL}$, respectively. The maximum proliferation of MDCK cells on the starch microcarrier and Cytodex 1 were $2.2 \times 10^{6}$ cells $/ \mathrm{mL}$ and 2.4 $\times 10^{6}$ cells $/ \mathrm{mL}$, respectively. Both of these two results indicate that the Marc-145 cells and MDCK cells growth on DEAE-CSM suspension performed a slight lower cell density compared to those growths on Cytodex 1 . The data shows that the DEAE-CSM microcarrier allows cell growth of three different cell lines to a high density, slightly lower than Cytodex 1 does.

\section{Conclusions}

The present study provides a low cost, simple emulsion crosslinking method to prepare DEAE-linked soybean starch microsphere microcarriers using natural soybean starch polymer as the raw material. Spinner flask culture showed that BHK-21, Marc-145, and MDCK cells were able to adhere to the starch microcarrier with good growth proliferation, comparable to that observed for Cytodex 1. These results show that DEAE-CSM microcarriers are promising economic alternative microcarriers for large-scale cultures of three adherent mammal cells, BHK-21, Marc-145, and MDCK cells.

\section{Acknowledgements}

This research was financially supported by the research Grant KY201501005 of the Ministry of Science and Technology of China, the Grant 2014-1-158 of Lanzhou Science and Technology, and the Grant h2011-6 of Cooperative Project between Northwest Minzu University and Enterprise.

\section{References}

Björses, K., Faxälv, L., Montan, C., Wildt-Persson, K., Fyhr, P., Holst, J., \& Lindahl, T. L. (2011). In vitro and in vivo evaluation of chemically modified degradable starch microspheres for topical haemostasis. Acta Biomaterialia, 7, 2558-2565. https://doi.org/10.1016/j.actbio.2011.03.003 
Cer, E., Gurpinar, O. A., Onur, M. A., \& Tuncel, A. (2007). Polyethylene glycol-based cationically charged hydrogel beads as a new microcarrier for cell culture. J. Biomed. Mater. Res. Appl. Biomater., 80, 406-414. https://doi.org/10.1002/jbm.b.30611

Chen, X. G., Liu, C. S., \& Liu, C. G. (2006). Preparation and biocompatibility of chitosan microcarriers as biomaterial. Biochem. Eng. J., 27, 269-274. https://doi.org/10.1016/j.bej.2005.08.021

Costa, A. R., Withers, J., Rodrigues, M. E., McLoughlin, N., Henriques, M., Oliveira, R., \& Azeredo, J. (2013). The impact of cell adaptation to serum-free conditions on the glycosylation profile of a monoclonal antibody produced by Chinese hamster ovary cells. $N$ Biotechnol., 25, 30(5), 563-572. https://doi.org/ 10.1016/j.nbt.2012.12.002

Delval, F., Crini, G., Bertini, S., Filiatre, C., \& Torri, G. (2005). Preparation, Characterization and Sorption Properties of Crosslinked Starch-Based Exchangers. Carbohydr. Polymers., 60, 67-75. https://doi.org/ 10.1016/j.carbpol.2004.11.025

Edman, P., Björk, E., \& Rydén, L. (1992). Microspheres as a nasal delivery system for peptide drugs. J. Contr. Release, 21, 165-172. https://doi.org/10.1016/0168-3659(92)90018-M

Freshney, R. I. (2010). Culture of Animal Cells: A Manual of Basic Technique and Specialized Applications (6th ed.). Jone Wiley Sons Inc. https://doi.org/10.1002/9780470649367

Gumusderelioglu, M., Cakmak, S., Timucin, H. O., \& Cakmak, A. S. (2013). Thermosensitive PHEMA microcarriers: ATRP synthesis, characterization, and usabilities in cell cultures. J. Biomater. Sci. Polym. Ed., 24, 2110-2125. https://doi.org/10.1080/09205063.2013.827104

Helan, X., Hazal, C., Bingnan, M., \& Yiqi, Y. (2015). Robust and Flexible Films from 100\% Starch Cross-Linked by Biobased Disaccharide Derivative. ACS Sustainable Chem. Eng., 3(11), 2631-2639. https://doi.org/10.1021/acssuschemeng.5b00353

Hoover, R., \& Ratnayake, W. S. (2002). Starch characteristics of black bean, chick pea, lentil, navy bean and pinto bean cultivars grown in Canada. Food Chem., 78, 489-498. https://doi.org/10.1016/S0308-8146(02) 00163-2

Jayasekara, R., Harding, I., Bowate, R. I., Christie, G. B. Y., \& Lonergan, G. T. (2004). Preparation, surface modification and characterisation of solution cast starch PVA blended films. Polymer. Test., 23(1), 17-27. https://doi.org/10.1016/S0142-9418(03)00049-7

Nienow, A. W., Rafiq, Q. A., Coopman, K., \& Hewitt, C. J. (2014). A potentially scalable method for the harvesting of hMSCs from microcarriers. Biochem. Eng. J., 85, 79-88. https://doi.org/10.1016/j.bej. 2014.02.005

Paris, M. S., Eaton, D. L., Sempolinski, D. E., \& Sharma, B. P. (1983). A gelatin microcarrier for cellculture. Vitro J. Tissue Culture Assoc., 19, 262.

Park, Y., Chen, Y., \& Ordovas, L. (2014). Hepatic differentiation of human embryonic stem cells on microcarriers. J. Biotechnol., 174, 39-48. https://doi.org/10.1016/j.jbiotec.2014.01.025

Ratnayake, W. S., Hoover, R., \& Warkentin, T. (2002). Pea Starch: Composition, Structure and Properties-A Review. Starch-Stärke, 54(6), 217-234. https://doi.org/10.1002/1521-379X(200206)54:6\%3C217::AID-STA R217\%3E3.0.CO;2-R

Reuveny, S., \& Thoma, R. W. (1986). Apparatus and methodology for microcarrier cell culture. Adv. Appl. Microbiol., 31, 139-179. https://doi.org/10.1016/S0065-2164(08)70441-6

Reuveny, S., Mizrahi, A., Kotler, M., \& Freeman, A. (1983). Mammalian cell propagation on derivatized polyacrylamide microcarriers. Dev. Biol.Stand., 55, 11-23.

Rodrigues, M. E., Costa, A. R., Fernandes, P., Henriques, M., Cunnah, P., Melton, D. W., ... Oliveira, R. (2013). Evaluation of macroporous and microporous carriers for $\mathrm{CHO}-\mathrm{K} 1$ cell growth and monoclonal antibody production. J. Microbiol. Biotechnol., 23, 1308-1321. https://doi.org/10.4014/jmb.1304.04011

Song, Z., Williams, C. J., \& Edyvean, R. G. J. (2004). Treatment of tannery wastewater by chemical coagulation. Desalination, Leeds, 164, 49-259. https://doi.org/10.1016/s0011-9164(04)00193-6

Stich, S., Ibold, Y., Abbas, A., Ullah, M., Sittinger, M., Ringe, J., ... John, T. (2014). Continuous cultivation of human hamstring tenocytes on microcarriers in a spinner flask bioreactor system. Biotechnol. Prog., 1, 142-51. https://doi.org/10.1002/btpr.1815 
Sun, Z., Xu, L., Guo, W., Xu, B., Liu, S., \& Li, F. (2010). Enhanced Photoelectrochemical Performance of Nanocomposite Film Fabricated by Self-Assembly of Titanium Dioxide and Polyoxometalates. J. Phy. Chem. C, 114(11), 5211-5216. https://doi.org/10.1021/jp910665b

Ting, S., Chen, A., Reuveny, S., \& Oh, S. (2014). An intermittent rocking platform for integrated expansion and differentiation of human pluripotent stem cells to cardiomyocytes in suspended microcarrier cultures. Stem Cell Res., 13, 202-213. https://doi.org/10.1016/j.scr.2014.06.002

Van Wezel, A. L. (1967). Growth of cell-strains and primary cells on micro-carriers in homogeneous culture. Nature, 216, 64-65. https://doi.org/10.1038/216064a0

Yuan, M. L., Zhang, Q. L., Guo, Z. L., \& Wang, J., \& Shen, Y. Y. (2015). The Complete Mitochondrial Genome of Corizus tetraspilus (Hemiptera: Rhopalidae) and Phylogenetic Analysis of Pentatomomorpha. PLoS One, 4, 10(6), e0129003.1-21. https://doi.org/10.1371/journal.pone.0129003

Zuhlke, A., Roder, B., Widdecke, H., \& Klein, J. (1993). Synthesis and application of new microcarriers for animal cell culture. Part I: Design of polystyrene based microcarriers. J. Biomater. Sci. Polym. Ed., 5, 65-78. https://doi.org/10.1163/156856294X00653

\section{Copyrights}

Copyright for this article is retained by the author(s), with first publication rights granted to the journal.

This is an open-access article distributed under the terms and conditions of the Creative Commons Attribution license (http://creativecommons.org/licenses/by/4.0/). 